\title{
Germination and fungal infection of wild celery (Apium graveolens L.) seeds, from southern Brazil, under different temperature and disinfection conditions
}

\author{
Kennia Brum Doncato ${ }^{1 *}$ DD, César Serra Bonifácio Costa ${ }^{2}$ \\ $10.1590 / 0034-737 X 201966050010$
}

\begin{abstract}
Seeds of wild celery (Apium graveolens $\mathrm{L}$.) from southern Brazil were surface disinfected with different solutions of sodium hypochlorite (5 and 10\%) and acetic acid $(0.5,1,2,4 \%)$, and germination success and fungal infection were evaluated after 28 days of incubation at a constant temperature of $30^{\circ} \mathrm{C}$ and $20 / 30^{\circ} \mathrm{C}$ thermoperiod (12h: $\left.12 \mathrm{~h}\right)$. Germination of wild celery was inhibited at the constant temperature $\left(30^{\circ} \mathrm{C}\right)$. Vigorous total germination $(90-100 \%)$, a faster germination velocity (1.8-2.5 germinated seeds per day) and moderate fungal infection $(53.3-81.7 \%)$ of wild celery seeds were obtained with the sodium hypochlorite treatments (5-10\% concentration) under the $20 / 30{ }^{\circ} \mathrm{C}$ thermoperiod. The $4 \%$ treatment of acetic acid was very effective at preventing seed fungal infection (only $5 \%$ of the seeds) but it reduced the average total germination to $60 \%$. Lower concentrations of acetic acid (0.5-2\%) resulted in $100 \%$ fungal infection. In conclusion, seedlings of wild celery from southern Brazil can be effectively produced by disinfecting the seeds with 5-$10 \%$ sodium hypochlorite and incubation under a $20 / 30^{\circ} \mathrm{C}$ thermoperiod (12h:12h).
\end{abstract}

Keywords: acetic acid; fungi; sodium hypochlorite; prophylaxis.

\section{INTRODUCTION}

Apium graveolens (Apiaceae) is an herbaceous marshland plant commonly used for consumption since antiquity, mainly due to its unique taste, nutritional composition, fiber content and innumerous pharmaceutical uses (Yao et al., 2010; Shad et al., 2011; Uddin et al., 2015). Browers \& Orton (1986) stated that A. graveolens is distributed in coastal marshes of Eastern Europe, Asia Minor, North Africa and North America, and that three botanical varieties of celery (i.e., var. dulce, rapaceum and secalinum) were domesticated (also called smallage and marsh parsley). Nowadays, several cultivar varieties (cvs.) of celery are found worldwide (Yao et al., 2010; Uddin et al., 2015).

Wild celery varieties have an increasing market interest and horticultural value, due to their growth behavior (i.e., elongated) and peculiar flavor (i.e., pungent acrid) (Browers \& Orton, 1986; Yao et al., 2010), since customers of gourmet foods are more open to new varieties of edible vegetables. Some A. graveolens varieties have a marked salt tolerance (i.e., halophytes) inherited from their ancestors that inhabited salt marshes (Everard, 1994), and cultivating these varieties with irrigated salt or brackish water can be marketed as environmentally friendly due to fresh water conservation, which increases the value of these vegetables. In southern Brazil, Costa (1997) recorded a biannual halophytic variety of $A$. graveolens that occurs in salt marshes of the Patos Lagoon estuary. This wild variety has free phenolic compounds content (known bioactive compounds) that is 10 -fold greater than values found in commercial celery cultivars (Souza et al., 2018). However, initial studies about the domestication of this halophytic variety had a major setback due to intense seed

\footnotetext{
Submitted on May 31 st, 2019 and accepted on September $7^{\text {th }}, 2019$.

${ }^{1}$ Programa de Pós-Graduação em Aquicultura, Instituto de Oceanografia, Universidade Federal do Rio Grande (FURG), Rio Grande, Rio Grande do Sul, Brasil.

${ }^{2}$ Laboratório de Biotecnologia de Halófitas, Instituto de Oceanografia, Universidade Federal do Rio Grande (FURG), Rio Grande, Rio Grande do Sul, Brazil. costacsb@gmail.com

* Corresponding author: kenniadoncato@hotmail.com
} 
infestation by fungi during germination. In Brazil, main fungal diseases recorded for commercial A. graveolens var. dulce are produced by seedborn fungi Rhizoctonia solani, Pythium spp., Phytophthora nicotianae and Alternaria dauci (Reis et al., 2018). According to Silveira (2012) Rhizoctonia sp. is one of most frequent fungi occurring on leaves of salt marsh plants of Patos Lagoon estuary during summer-autumn, but no proper identification of fungi on seeds of the halophytic variety of $A$. graveolens was done.

According to Coolbear et al. (1992), A. graveolens is known for being difficult in relation to germination and establishment. Temperature and photoperiod can influence the germination of $A$. graveolens, and there are different responses among the varieties (Thompson, 1974). Seed germination of this species usually takes a long time and there is some asynchrony under suboptimal temperatures (Van der Toorn \& Karssen, 1992). The pericarp of celery seeds has alternating longitudinal furrows (yellowish parts) and ridges (darkish parts), and schizogenous oil tubes run beneath the furrows (Hopkins, 1927). Volatile oil obtained from celery seeds is used in the perfume and pharmaceutical industries (Shad et al., 2011), but the presence of ridges and oil tubes on the seed pericarp make it difficult to clean the seeds, favoring the development of fungi during germination. Surface seed disinfection by germicide application is necessary to remove microorganisms that may interfere with germination (Abdul-Baki \& Moore, 1979).

Among the many alternatives, sodium hypochlorite and acetic acid are the most affordable and easy to find, because they are used domestically as household bleach and vinegar, respectively. Sodium hypochlorite $(\mathrm{NaOCl})$ is a chemical typically used as a sterilizing agent of seeds, since it does not affect seed germination and seedling growth (Abdul-Baki \& Moore, 1979). Acetic acid $\left(\mathrm{CH}_{3} \mathrm{COOH}\right)$ is an organic acid used as a seed disinfectant and adopted by organic agriculture, since it has low eco-toxicological risk (Van der Wolf et al., 2008). Besides the need to control seed infestation by microorganisms, exposure time and concentration of a disinfectant can affect seed germination and may lead to losses in viability. Thus, the establishment of a proper disinfectant procedure for seeds can improve germination percentage and the successful establishment of A. graveolens plantlets. The aim of the present study was to evaluate applications of sodium hypochlorite and acetic acid as disinfectants and to determine the best temperature for germination of the halophytic wild variety of celery (A. graveolens) found in southern Brazil.

\section{MATERIALAND METHODS}

\section{Material}

Seeds of the halophytic wild variety of $A$. graveolens were collected in the Pólvora Island salt marsh located in the Patos Lagoon estuary, Rio Grande, RS ( $32^{\circ} 01^{\prime} \mathrm{S}$; $\left.52^{\circ} 06^{\prime} \mathrm{W}\right)$. The seeds were dried at room temperature $\left(20 / 25^{\circ} \mathrm{C}\right.$ ) for 30 days and then stored at $5{ }^{\circ} \mathrm{C}$ in the germplasm bank of the Laboratório de Biotecnologia de Halófitas (Instituto de Oceanografia - IO, Universidade Federal do Rio Grande - FURG) for six months before the experiments.

\section{Experiment 1. Temperature effect on germination and fungal infestation}

Seeds were surface sterilized by soaking them for 5 minutes using three disinfection solutions: $5 \%$ and $10 \%$ sodium hypochlorite, and $4 \%$ acetic acid. The concentrations of sodium hypochlorite were made from a dilution of $2.5 \%$ active chlorine (common concentration of Brazilian household bleach) and the concentration of acetic acid was made from Brazilian vinegar (4\% acetic acid; Brazil, 2000); they were prepared with pure chemicals. After disinfection, the seeds were rinsed with distilled water and placed in autoclaved Petri dishes with filter paper dampened with $6 \mathrm{~mL}$ of distilled water. The Petri dishes were placed in germination chambers at a constant temperature of $30^{\circ} \mathrm{C}$ and thermoperiod of $20 / 30^{\circ} \mathrm{C}$. Seed incubation lasted for 28 days and both chambers had a photoperiod of $12 \mathrm{~h}$ light $/ 12 \mathrm{~h}$ dark $\left(40 \mu \mathrm{mol}\right.$ photons $\mathrm{m}^{-2} \mathrm{~s}^{-}$ 1, 400-700 nm; provided by cold white fluorescent light). Three Petri dishes with 20 seeds were used as replicates of each treatment. Seed germination (radicle protrusion) was recorded every week and the percentage of seeds with fungal infestation after one week of incubation was used as a proxy of disinfection efficiency. For this procedure individual seeds were graded according to a 2 - digit pathogenicity scale ( 0 and 1$)$; whereby 0 indicates without fungi, 1 = with fungi. Due to the high fungal infestation at the end of first week, the disinfection treatments were once repeated.

\section{Experiment 2. Disinfection procedure effect on germination and fungal infestation}

Due to the strong inhibition of seed germination by the $4 \%$ acetic acid solution, three additional disinfection treatments with lower concentrations of acetic acid $(0.5 \%$, $1 \%$ and $2 \%$ ) were tested in a second 28-day trial using only the $20 / 30{ }^{\circ} \mathrm{C}$ thermoperiod. This second experiment used the same photoperiod, number of seeds per Petri dish and number of replicates as the first experiment.

\section{Statistical analysis}

Germination speed index (GSI) was calculated as described in Maguire (1962) and expressed in germinated seeds per day. Average values of total germination percentage and percentage of seeds with fungal infection were compared between temperatures $\left(20 / 30^{\circ} \mathrm{C}\right.$ and $\left.30^{\circ} \mathrm{C}\right)$ 
and among disinfection treatments (5\% and $10 \%$ sodium hypochlorite, and $4 \%$ acetic acid) using a bifactorial ANOVA. Data for the disinfection treatments of both germination trials exposed to the thermoperiod were combined and the total germination percentage, GSI and percentage of seeds with fungal infection were compared with a one-way analysis of variance (ANOVA). Germination speed index values for the constant temperature $\left(30^{\circ} \mathrm{C}\right)$ were not calculated due to the absence of germination under this experimental condition. The requirements of normality and homoscedasticity for the ANOVA procedures (Zar, 2010) were evaluated using Shapiro-Wilk's and Levene's tests, respectively. Significant differences in the ANOVA $(\mathrm{p}<0.05)$ were followed by Fisher's least difference (LSD) test at 5\% significance.

\section{RESULTS AND DISCUSSION}

The germination and seed fungal infection data are in Tables 1 and 2 . At a constant temperature of $30^{\circ} \mathrm{C}$ (Table 1 ), no germination of the wild celery seeds occurred after 28 days of incubation. In contrast, at the $20 / 30{ }^{\circ} \mathrm{C}$ thermoperiod up to $100 \%$ of the seeds germinated when they were disinfected with sodium hypochlorite. Previously, Morinaga (1926) found a maximum germination for A. graveolens (cvs. Dreers Monarch and Columbia) between $50-70 \%$ at a $22 / 32{ }^{\circ} \mathrm{C}$ thermoperiod. Thompson (1974) also reported that a thermoperiod of $22 / 25^{\circ} \mathrm{C}$ was most effective for the germination of other cultivar varieties of A. graveolens (cvs. Golden Self-blanching, Avon Pearl, Lathom blanching, Giant Red and Solid White), but he noted that germination velocity response to temperature can be different for each celery variety. Concerning the effect of constant temperatures, Hopkins (1927) worked with cultivar varieties of celery and Parera et al. (1993) studied non-primed A. graveolens seeds (cv. M-68-29-5) and found overall seed germination percentages of $28 \%$ and $2 \%$ at $30{ }^{\circ} \mathrm{C}$, respectively. Coolbear et al. (1992), working with pre-imbibed seeds of two cultivars of $A$. graveolens (cvs. Tall Utah 52-70 and Green Giant Hybrid), recorded only an average of $6 \%$ germination of seeds exposed to $25^{\circ} \mathrm{C}$ for 34 days. Morinaga (1926) observed no germination for varieties of A. graveolens at $32^{\circ} \mathrm{C}$ for 30 days. According to Biddington et al. (1980), a high temperature $\left(32^{\circ} \mathrm{C}\right)$ may induce secondary dormancy of $A$. graveolens seeds (cv. Lathom Blanching), possibly preventing embryo development and endosperm breakdown, making the seed deal directly or indirectly (preimbibed and dried seeds) with desiccation.

Fungal disinfection of wild $A$. graveolens seeds was statistically better for the $4 \%$ acetic acid treatment (lowest fungal infection $=5 \%$ of the seeds), but this procedure strongly inhibits the average total germination $(60 \%$ at the $20 / 30{ }^{\circ} \mathrm{C}$ thermoperiod after 28 days). Lowering the concentration of acetic acid (0.5-2\%) led to fungal infection of $100 \%$ of the seeds, lower germination velocities and smaller final total germination than seeds disinfected with sodium hypochlorite (Table 2). Similarly, Van der Wolf et al. (2008) found a marked decrease in disinfection efficiency of acetic acid on seed-associated bacteria with this dilution. According to Doran (1929), acetic acid may have a toxic effect on higher plants. For the sodium hypochlorite treatments, $53.3-81.7 \%$ of seeds were infected by fungi after one week of incubation, but the seeds showed high germination velocities (average GSI $=1.8-2.5$ germinated seeds per day) and final total germination values above $90 \%$. Pathogenicity scale did not distinguish several levels of infestation (only infected and not infected seeds), but the results suggest that sodium hypochlorite treatments were effective to inhibit fungi seed damage, and the most concentrated solution allowed the highest

Table 1: Mean \pm (standard error) of the total germination and fungal infection of the wild A. graveolens under thermoperiod and constant temperature among disinfection treatments. Summary of two-way ANOVA results for all parameters among disinfection levels and seed incubation temperatures are presented

\begin{tabular}{|c|c|c|c|c|}
\hline \multirow{2}{*}{ Treatment } & \multicolumn{2}{|c|}{ Total germination $(\%)$} & \multicolumn{2}{|c|}{ Fungal infection (\%) } \\
\hline & $20 / 30^{\circ} \mathrm{C}^{\$}$ & $30^{\circ} \mathrm{C}$ & $20 / 30{ }^{\circ} \mathrm{C}$ & $30{ }^{\circ} \mathrm{C}$ \\
\hline $5 \% \mathrm{NaOCl}$ & $\begin{array}{c}90.0 \mathrm{c} \\
(5.8)\end{array}$ & $\begin{array}{l}0.0 \mathrm{a} \\
(0.0)\end{array}$ & $\begin{array}{c}53.3 \mathrm{~b} \\
(8.8)\end{array}$ & $\begin{array}{c}68.2 \mathrm{bc} \\
(5.6)\end{array}$ \\
\hline $10 \% \mathrm{NaOCl}$ & $\begin{array}{c}100.0 \mathrm{~d} \\
(0.0)\end{array}$ & $\begin{array}{l}0.0 \mathrm{a} \\
(0.0)\end{array}$ & $\begin{array}{l}81.7 \mathrm{c} \\
(10.9)\end{array}$ & $\begin{array}{c}65.2 \mathrm{bc} \\
(2.2)\end{array}$ \\
\hline $4 \% \mathrm{CH}_{3} \mathrm{COOH}$ & $\begin{array}{c}60.0 \mathrm{~b} \\
(2.9)\end{array}$ & $\begin{array}{l}0.0 \mathrm{a} \\
(0.0)\end{array}$ & $\begin{array}{l}5.0 \mathrm{a} \\
(2.9)\end{array}$ & $\begin{array}{l}6.1 \mathrm{a} \\
(1.5)\end{array}$ \\
\hline F Disinfection & \multicolumn{2}{|c|}{$31.2(* * *)$} & \multicolumn{2}{|c|}{$46.1(* * *)$} \\
\hline F Temperature & \multicolumn{2}{|c|}{$1500.0(* * *)$} & \multicolumn{2}{|c|}{$0.00(\mathrm{~ns})$} \\
\hline F Disinfection $\mathrm{x}$ Temperature & \multicolumn{2}{|c|}{$31.2(* * *)$} & \multicolumn{2}{|c|}{$1.2(\mathrm{~ns})$} \\
\hline
\end{tabular}

$\$$ Different lowercase letters represent significant differences between temperatures and disinfection treatments, according to Fisher's least difference (LSD) test at $5 \%$ significance. ${ }^{*} \mathrm{p}<0.05 ; * * \mathrm{p}<0.01$; $* * * \mathrm{p}<0.001$; ns: non-significant $(\mathrm{p}>0.05)$. 
Table 2: Mean \pm (standard error) of the total germination, germination speed index (GSI) and fungal infection of the wild A. graveolens under thermoperiod among disinfection treatments. Summary of one-way ANOVA results for all parameters among disinfection treatments are presented

\begin{tabular}{lccc}
\hline Treatment & $\begin{array}{c}\text { Total germination } \\
(\boldsymbol{\%})^{\$}\end{array}$ & $\begin{array}{c}\text { GSI } \\
\text { (Germinated seeds per day) }\end{array}$ & $\begin{array}{c}\text { Fungal infection } \\
(\%)\end{array}$ \\
\hline $5 \% \mathrm{NaOCl}$ & $90.0 \mathrm{c}$ & $1.8 \mathrm{ab}$ & $53.3 \mathrm{~b}$ \\
& $(5.8)$ & $(0.2)$ & $(8.8)$ \\
$10 \% \mathrm{NaOCl}$ & $100.0 \mathrm{c}$ & $2.5 \mathrm{c}$ & $(1.7 \mathrm{c}$ \\
& $(0.0)$ & $(0.0)$ & $100.9)$ \\
$0.5 \% \mathrm{CH}_{3} \mathrm{COOH}$ & $75.0 \mathrm{~b}$ & $2.1 \mathrm{bc}$ & $(0.0)$ \\
& $(2.9)$ & $(0.1)$ & $100.0 \mathrm{~d}$ \\
$1 \% \mathrm{CH}_{3} \mathrm{COOH}$ & $68.3 \mathrm{ab}$ & $1.7 \mathrm{ab}$ & $(0.0)$ \\
& $(1.7)$ & $(0.2)$ & $100.0 \mathrm{~d}$ \\
$2 \% \mathrm{CH}_{3} \mathrm{COOH}$ & $70.0 \mathrm{ab}$ & $1.4 \mathrm{a}$ & $(0.0)$ \\
$4 \% \mathrm{CH}_{3} \mathrm{COOH}$ & $(7.6)$ & $(0.2)$ & $5.0 \mathrm{a}$ \\
$\mathrm{F}$ & $60.0 \mathrm{a}$ & $1.6 \mathrm{a}$ & $(2.9)$ \\
\hline
\end{tabular}

${ }^{\$}$ Different lowercase letters (within a column) represent significant differences between disinfection treatments, according to Fisher's least difference (LSD) test at 5\% significance. $* \mathrm{p}<0.05 ; * *<0.01 ; * * \mathrm{p}<0.001 ;$ ns: non-significant $(\mathrm{p}>0.05)$.

total germination. Taylor (1949) and Abdul-Baki \& Moore (1979) pointed out that $A$. graveolens cultivar varieties responded well to concentrated sodium hypochlorite solutions, being the total germination of A. graveolens $\mathrm{cv}$. Detroit Golden reduced somewhat by the solutions of $1.5 \%$ and 2\% "active chlorine" tolerated by cv. Tall Utah (Taylor, 1949).

\section{CONCLUSIONS}

Seedlings of wild celery can be effectively produced by disinfecting the seeds with 5-10\% sodium hypochlorite and incubating them under a $20 / 30{ }^{\circ} \mathrm{C}$ thermoperiod (12h:12h).

\section{REFERENCES}

Abdul-Baki AA \& Moore GM (1979) Seed disinfection with hypoclorite: A selected literature review of hypoclorite chemistry and definition of terms. Journal of Seed Technology, 4:43-56.

Biddington NL, Thomas TH \& Dearman AS (1980) The promotive effect on subsequent germination of treating imbibed celery seeds with high temperature before or during drying. Plant, Cell and Environment, 3:461-465.

Brazil (2000) Normative instruction number 36 of October 14 1999. Technical regulamentation for fixation of identity and quality standards for fermented acetic acids. DOU, 15/10/1999, Section 1, p.76.

Browers MA \& Orton TJ (1986) Celery (Apium graveolens L.). In: Bajaj YPS (Ed.) Biotecnology in Agriculture and Forestry 2: Crops I. Berlin, Springer-Verlag. p. 405-420.

Coolbear P, Toledo PE \& Seetagoses U (1992) Effects of temperature of pre-sowing hydration treatment and subsequent drying rates on the germination performance of celery seed. New Zealand Journal of Crop and Horticultural Science, 19:09-14.
Costa CSB (1997) Tidal marsh and wetland plants. In: Seeliger U \& Castello JP (Eds.) Substropical convergence environments The coast and sea in the Southwestern Atlantic. Berlin, SpringerVetlag. p. 24-26.

Doran WL (1928) Acetic acid as a soil disinfectant. Journal of Agricultural Research, 36:269-280.

Everard JD, Gucci R, Kann SC, Flore JA \& Loescher WH (1994) Gas exchange and carbon partitioning in the leaves of celery (Apium graveolens L.) at various levels of root zone salinity. Plant Physiology, 106:281-292.

Hopkins EF (1927) A study of the seed of Apium graveolens Linn: With special reference to the effect of light, temperature, disinfectants, and other factors upon germination. Master Thesis. University of Massachusetts Amherst, Amherst. 62 p.

Maguire JD (1962) Speed of germination - Aid in selection and evaluation for seedling emergence and vigor. Crop Science, 2:176-177.

Morinaga T (1926) Effect of alternating temperatures upon the germination of seeds. American Journal of Botany, 13:141-158.

Parera CA, Qiao P \& Cantliffe DJ (1993) Enhanced celery germination at stress temperature via solid matrix priming. HortScience, 28:20-22.

Reis A, Lopes C \& Henz G (2018) Principais doenças da salsa no Brasil. Brasília, Embrapa Hortaliças. 28p. (Circular Técnica, 165).

Shad AA, Shah HU, Bakht J, Choudhary MI \& Ullah J (2011) Nutraceutical potential and bioassay of Apium graveolens L. grown in Khyber Pakhtunkhwa-Pakistan. Journal of Medicinal Plants Research, 5:5160-5166.

Silveira ES (2012) Fungos e leveduras na água e plantas macrófitas em decomposição na região estuarina da Lagoa dos Patos e praia do Cassino, RS - Brasil. Tese de Doutorado. Universidade Federal do Rio Grande, Rio Grande. 134p.

Souza MM, Silva B, Costa CSB \& Badiale-Furlong E (2018) Free phenolic compounds extraction from Brazilian halophytes, soybean and rice bran by ultrasound-assisted and orbital shaker methods. Anais da Academia Brasileira de Ciências, 90:33633372 .

Rev. Ceres, Viçosa, v. 66, n.5, p. 402-406, sep/oct, 2019 
Taylor CA (1949) Some factors affecting germination of celery seed. Plant Physiology, 24:93-102.

Thompson PA (1974) Germination of celery (Apium graveolens L.) in response to fluctuating temperatures. Journal of Experimental Botany, 25:156-163.

Uddin ZU, Shad AA, Bakht J, Ullah I \& Jan S (2015) In vitro antimicrobial, antioxidant activity and phytochemical screening of Apium graveolens. Pakistan Journal Pharmaceutical Sciences, 28:1699-1704.

Van der Toorn P \& Karssen CM (1992) Analysis of embryo growth in mature fruits of celery (Apium graveolens). Physiologia Plantarum, 84:593:599.
Van der Wolf JM, Birnbaum Y, Van der Zouwen PS \& Goot SPC (2008) Disinfection of vegetable seed by treatment with essential oils, organic acids and plant extracts. Seed Science \& Technology, 36:76-88.

Yao Y, Sang W, Zhou M \& Ren G (2010) Phenolic composition and antioxidant activities of 11 celery cultivars. Journal of Food Sciences, 75:C9-C13.

Zar JH (2010) Biostatistical analysis. New York, Prentice-Hall. 944 p. 